\title{
TECHNICAL CULTURE AND HUMAN AXJOSPHERE
}

\section{Krystyna Chałas ${ }^{1}$}

1 The John Paul II Catholic University of Lublin, Al. Racławickie 14, 20-950 Lublin, Poland, e-mail: kryschal@kul. lublin.pl

Received: 2014.09.25

Accepted: 2014.10.25

Published: 2014.12.01

\begin{abstract}
Technical culture is the value of each historical period. It is the subject of the ongoing development. While it is a value which is associated with different categories of values, mainly material, cognitive, social. Between culture and these three categories of values there is a cognitive effect. Technical culture determines the quality of human axjosphere. The aim of this study is to show the relationships and dependencies between technical culture and the structures in which a person lives and works. It is mainly about the answer to the question of which values of technical culture are closely related to and what are the inter dependencies?

The primary task is to define the concept of the technical culture and to show its teaching essence. The second task boils down to indicate the range of values inherent in the culture of technology, determining the value of the technological culture and values, which are developed by the technical culture. Indication of the interaction between the technical culture and values is the third task.
\end{abstract}

Keywords: technical culture, values, axjosphere.

\section{THE TECHNICAL CULTURE AS A VALUE}

Without going into a detailed analysis of the concept of the technical culture, it should be emphasized that it has the position in the concept of culture. In general, culture is understood as "general spiritual and material heritage of mankind made in the subsequent stages of historical development, continuously recorded and enriched" [1].

According to this definition of $\mathrm{H}$. Pochanke, the technological culture is "the whole of the social acquis in the field of technical sciences and its use, and at the same time, as all the knowledge and skills needed to understand the achievements, correct use of it, transmission to the younger generation and createing new values in this area" [2].

The author distinguishes the objective and subjective aspect of the technical culture. In terms of present technological culture there is the totality of the social acquits in the field of technical sciences, its use and the general knowledge and skills needed to understand this acquis. In the technological culture here is a contracting party to three closely related groups of elements: adequate supply and the level of technical knowledge; team skills of motor and fitness and intellectual aspect; appropriate level of socio-moral sphere, manifesting itself in desired human attitudes towards technology and related actions [3].

\section{TECHNICAL CULTURE AND THE VALUE OF A PERSON}

The link integrating the technological culture of the said technical culture is man's subjective the human person. The personal nature of many consequences of human nature is axiological. Firstly, the person is committed to the development of the technical culture in the present dimension, aiming to respect person's dignity, values, quality of life and are both in the individual as well as the social identity. The man - a person wandering into the fullness of humanity through the realization of the values of dignity, wisdom, freedom, responsibility, love, and transcendence 
builds the same technological culture serving the culture of life. Consequently, technical culture must recognize the fundamental value of life, which according to J. Nagorno means that "human life as a precious gift of God, is sacred and inviolable:

- human life is not allowed to be kill, but it must be protected with loving care;

- life finds its meaning, when we give and receive love;

- this love gives meaning to suffering and death, which can thus become a saving event;

- the subordination of science and technology, man and his integral development comes out of respect for life flows;

- the whole of society must respect, protect and promote the dignity of every human person, at any time and state of life" [3].

The same author points out that "in the modern world, learning the secrets of life processes is at the same time not always accompanied with a full recognition of the mystery of human life, its value and meaning. Modern man can do so much in the field of genetics, he can interfere with the processes of life in various ways, even in its transmission. The same man is able, however, to harness technique and technology, which should serve human life in such activities, which are aimed at the destruction of life" [3].

Thus, the technical culture can also become a generator of anti-values. It may be directed against a man, his integral development. It can also -especially the technology culture creators - "shrink" a man in his humanity and lead to stunting, spiritual impoverishment. The technical culture is and must be closely linked to the essence of man in his undeniable values. Neither the question nor the economy can lead to the objectification of man, considered man as a means to the goal. It should not lead to the manipulation of man [4]. It should be emphasized that modern technological advances, which state the technical culture, have created a tool that threats man in his essence, threats the lives of the individual and social dimension. In this way, the technical culture becomes a factor in building a culture of death.

The fundamental base of the technical culture is an integral concept of man as a person, and his dignity can connect people who are concerned about each other to save the man and his life to save a man in a man, the man entrusted to man, and therefore can reject the temptation of indifference, the temptation concerning their own interests and their own prosperity without the property of others or at the expense of another human being.

We cannot build the technical culture on partial truths about man, rejecting the essence of the human person, its great value. This is a departure from the truth of man resulting in dramatic phenomena in various fields of science and research disciplines. The crisis over the truth about man promotes consumer culture of material goods. It takes up consumer habits and wicked lifestyles. As J. Nagorny emphasized: "manifestation of the consumer civilization is an exaggerated propaganda of purely utilitarian values, which leads to the awakening of human instincts and gives birth to their unbridled desire for instant gratification. Hence, it is difficult to recognize and respect the true values of human existence" [3].

The crisis of humanity in man leads to building the technical culture directed against man, and thus against the social life, putting materialisticeconomic vision of life at its center.

In the context of what has been said above it should be noted that between the culture of technical and human - like any culture - there is a close relationship. Man creates the technological culture, which expresses and confirms himself, it serve to another person in the individual and social dimension. Through this subjective human involvement in building a culture of technical man develops and perfects himself. We can tell that culture creates man.

This relationship of technical culture of man becomes a platform to build structures forming the axjosphere. For this to happen a basic condition must be met: the adoption of the complete truth about man and about his integrity [5]. Otherwise, the technical culture becomes a source of generating structures counter-values.

The technical culture should decisively a contribute to building a new culture of life, to adopt a new lifestyle, encouraging a deepening of personal integrity.

\section{THE TECHNICAL CULTURE AND THE VALUES}

The technical culture includes:

- technological culture of consumers, users;

- technological culture of technology manufacturers;

- technological culture of technology creators. 
In this sense, technological culture "typed" is a defined value structure. The technical culture in the present dimension is the source of the material, which becomes an instrumental values supporting, facilitating, and sometimes that determine the life and functioning of man on earth.

Second, there are economic values, which on the one hand, arise due to material values, on the other hand, determine the formation of the material.

Technical culture is conditioned by economic structure of cognition. For cognitive values there are: knowledge, learning, wisdom, inventiveness, creativity [6]. It should be stressed that the learning the value by a young man of a positive attitude to the process of education and self-education, involvement in the acquisition of knowledge and skills is a factor in the development of thought, imagination, memory, attention. The above-mentioned values have their detailed exemplification in culture through technical and technological culture.

The condition for the development of the technical culture is the realization of these values, which in the process of its development assume a new dimension and quality, and ultimately expressed in the technical abilities.

In terms of the technical culture cognitive values are: technical knowledge, technology and science, technical understanding, as a function of technical intellect manifested in wisdom, ingenuity, and creativity expressed in the technical solutions inventions and patents. The basis on which arise cognitive values is a technical understanding, is technical thinking, technical imagination.

It is noteworthy the triad of the above analysis was conducted by E. Franus. By dealing with the formal aspect of understanding and examining students' understanding of the tools he identified three forms of understanding:

- "act of understanding, or recognition of already known objects, relationships, laws, principles, theories, etc.

- the process of understanding, that is, guessing meaning, role, importance by discovering mental attributes and the relationships between parts and their functions in order to understand an object, process, etc.;

- the effect of the process of understanding, which can either be understood if the process works correctly guessing either misunderstanding or lack of understanding" [7].
The author in technique distinguishes the understanding of technical drawings, tools, machinery, electrical circuits [8]. He treats understanding as criteria function of technical intellect. The second element for the formation of specific cognitive technique is the technical imagination. E. Franus defines the imagination as "the process of thinking, verbal and mental subordinate to the concept which consists in reproducing images from memory, turning them and connecting in new systems, according to the requirements of the task and of thinking" [8], distinguishes the following types of technical imagination:

- technical spatial thinking - "is a pictorial representation of the ability of technical objects or their components on the category, shape, size, position, and spatial location." - kinetic - "is the ability of ideational representation of the movements of individual and systems associated with the operation of technical objects, dynamic and static" [7];

- construction - "is the ability of image representation methods of constructing technical objects, namely structural and functional forming and joining structural elements, which use the ideas taken from memory resource, or generated on a regular basis together with creative thinking" [7];

- operational - "is the ability of imaging representation in a form of imaginative schemes, the course of technological operations and serving them in repeated action" [7].

The above mentioned basic types of the technical imagination are enriched with imagination of technical objects, imagination of plastic material, duration of surgery, imaginative graphic language characters, imaginative aesthetic presentation of technical creations [7]. The imaginative thinking operates technical specifications, using its ancillary function.

The technical thinking according to E. Franus is "the process of solving the understanding of technical tasks, characterized by: 1) a dual processual structure of the analytic-synthetic (cognitive-creative, with the course of two or multiphase filled micro fusion and final creative macro synthesis) and 2) a two-piece structure the said composed for a) subsystem science discovered the laws of nature, together with the requirements of ergonomics and ecology, and b) subsystem technical categories, concepts, ideas, graphic language, norms and principles of tech- 
nology in constructing or exploring new technical objects" [7].

This complex structure of the technical thinking allows us to distinguish some of its categories:

- practical thinking - thinking in action (meaning - motor, manipulative, reconnaissance);

- graphic thinking, technical drawing (restorative, creative);

- imaginative thinking;

- conceptual thinking [7].

In considering the relationship of technical culture - the cognitive, it is advisable to pay attention to the problem of technical intellect. According to E. Franus "technical intellect is an abstract mental structure formed in the course of technical training consisting of the ability to operate imaginative thinking in terms of technical ability to solve technical tasks with understanding and creative ingenuity to modern ideals of ergonomics and ecology" [7]. The technical intellect is "typed" with thinking and technical ability and creative ingenuity. Technical Intellect is a kernel of technical talent that determines the development of the technical culture and is a component of this technical culture in terms of contracting party. In it, it develops and confirms.

It should also be noted that technical intellect develops under the influence of technical culture substance, under the influence of technical products around us with what we meet every day. E. Franus stresses that "the process is independent of our will, but the level of its development is the result of the impact of our assessment on the one hand and demand for the products of technology in our everyday lives on the other hand" [7].

\section{CONCLUSIONS}

Building the culture of technology in terms of objective and subjective takes place due to another person and another person for another person. In the process of building draws from experiences and thoughts of other people. The technological culture "fits" the structure of the social values. These include homeland, nation, human rights, human dignity, peace, tolerance, justice, solidarity.

Development of the technical culture in terms of these values should serve multiple functions:

- development - development of the technical culture should contribute to the development of these values;

- guarantees security - development of technical culture should provide behavior, respect for these values.

On the other hand, the realization of the social values is a prerequisite for the development of the technical culture as the category of common good.

\section{REFERENCES}

1. Słownik współczesnego języka polskiego. Warszawa 1998, p. 441.

2. Pochanke M.: Podstawy dydaktyki techniki. Łódź 1985, p. 28.

3. Nagórny J.: Wartość życia ludzkiego. [In:] K. Jeżyna, J. Gocko, W. Rzepa (eds.), Lublin 2009, p. 32.

4. Śniadkowski M.: Ontologiczny wymiar człowieka w Sieci. [In:] Śniadkowski M. (ed.), Społecznopedagogiczna użyteczność technologii informacyjnych, t. 4, Lublin 2011, 7-35.

5. Gejdoš M.: Troska o integralny rozwój i wychowanie człowieka. [In:] M. Nowak, T. Ożóg, A. Rynio (eds.) "W trosce o integralne wychowanie". Lublin 2003, 205-211.

6. Denek K.: O nowy kształt edukacji. Toruń 1998.

7. Franus E.: Wielkie funkcje technicznego intelektu. Struktura uzdolnień technicznych, Kraków 2000., 69-167.

8. Franus E.: Myślenie techniczne. Kraków 1978, p. 65 . 